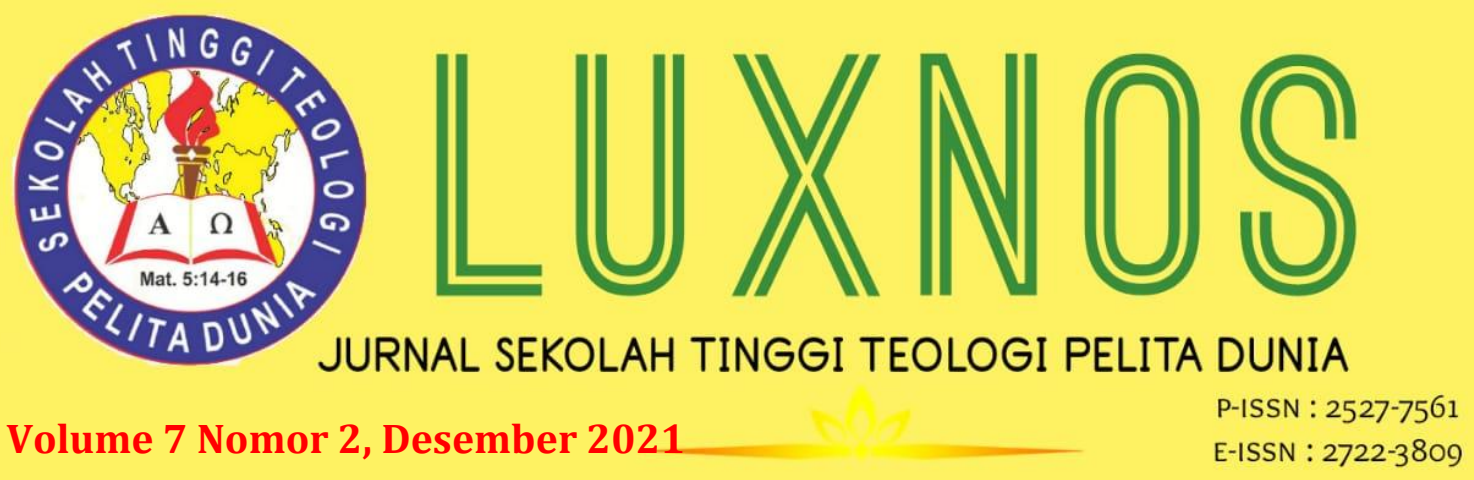

\title{
Providensia Allah di Masa Pandemi Covid-19
}

\author{
Hermanto ${ }^{1}$ \\ Sekolah Tinggi Teologi Pelita Dunia, Tangerang \\ hermantopitis@gmail.com
}

Sri Dwi Harti ${ }^{2}$

Sekolah Tinggi Teologi Pelita Dunia

dwiharti@hotmail.com

Charisal B.S. Manu ${ }^{3}$

Sekolah Tinggi Teologi Pelita Dunia

charisal_manu@yahoo.co.id

\begin{abstract}
The fall of man into sin, brings consequences and rewards that cannot be denied. In this case, man must bear the yoke of suffering caused by sin. Suffering will always be in touch wit human life, so that all humans cannot escape suffering. In the beginning, God made everyhting really very good, but human desires have polluted God's created world. Thus, human disease and suffering, caused by humans themselves, include deadly parasites and viruses. However, God never abandons the work of His hands. The purpose of this research it is to remind and strengthen beleivers in particular, to keep standing firm on Jesus Christ who is the steadfast rock. Thus, beleivers are expected to continue to have faith in God's providence, even in difficult times doe to the pandemic. The research method used is descriptive qualitative, with a library research data collection system through the help of books and related journal articles. In this study, it was found that even though humans are not faithful, God is still faithful to protect and care for creation. More than that, God through history demonstrated His sovereignty over the universe, namely through His foreknowledge of all things and made all things for His eternal purpose.
\end{abstract}

Keywords: Providence, God's and Pandemic.

Abstrak: Kejatuhan manusia kedalam dosa, membawa konsekuensi serta upah yang tidak dapat ditolak. Dalam hal ini, manusia harus memikul kuk penderitaan akibat yang ditimbulkan oleh dosa. Penderitaan akan selalu bersentuhan dengan kehdidupan manusia, sehingga semua manusia tidak dapat luput dari pendertaan. Pada mulanya, Allah menjadikan segala sesuatu sungguh amat baik, tetapi keinginan manusia telah membuat dunia ciptaan Allah menjadi tercemar. Dengan demikian, penyakit serta penderitaan manusia, disebabkan oleh manusia itu sendiri, termasuk parasit serta virus yang mematikan. Meskipun demikian, Allah sekali-kali tidak meninggalkan perbuatan tangan-Nya (providensia). Adapun tujuan dari penelitian ini adalah untuk 
mengingatkan serta menguatkan orang percaya secara khusus, untuk tetap berdiri teguh pada Yesus Kristus yang adalah batu karang yang teguh itu. Dengan demikian, orang percaya diharapkan tetap beriman pada pemeliharaan Allah, sekalipun di masa sulit akibat Pandemi. Adapun metode penelitian yang digunakan adalah kualitatif deskriptif, dengan sistem pengumpulan data library research melalui bantuan bukubuku serta artikel jurnal yang terkait. Dalam penelitian ini, ditemukan fakta bahwa sekalipun manusia tidak setia, Allah tetap setia untuk menjaga dan memelihara ciptaan. Lebih dari itu, Allah melalui sejarah menunjukkan kedaulatan-Nya atas alam semesta, yakni melalui pra-pengetahuan-Nya atas segala sesuatu dan menjadikan segala sesuatu untuk tujuan kekal-Nya.

Kata Kunci: Providensi, Allah dan Pandemi Covid-19.

\section{Pendahuluan}

Kitab Kejadian dengan jelas mengungkapkan bahwa Allah adalah Pencipta (Kej. 2:1-2). Allah menciptakan langit dan bumi dengan berfirman (Kej. 1:3, 6, 9, 11, 14, 20, $24,26)$, yakni firman yang berkuasa menciptakan dari ketiadaan menjadi ada (creatio ex nihilo). Karya penciptaan menunjukkan keteraturan serta kesatuan antara Pencipta dengan ciptaan (bdk. Kej. 2:15-25). Herman Bavinck memberikan komentar tentang keteraturam itu "sebagai kesempurnaan dalam jenis, dan bahwa Allah dari tempat-Nya yang agung melihat dengan sukacita buatan tangan-Nya dengan mengatakan bahwa semua sangat baik (Kej. 1:31)". ${ }^{1}$ Allah menciptakan segala sesuatu untuk tujuannya masing-masing. Keteraturan dalam penciptaan, yakni bahwa Allah telah mempersiapkan persediaan bagi manusia dengan menciptakan terlebih dahulu bendabenda penerang, daratan dan tumbuh-tumbuhan serta membentuk manusia sebagai klimaks dari narasi penciptaan. Hal-hal itu menunjukkan bahwa Allah telah menciptakan segala sesuatu yang dapat mendukung keberlangsungan hidup manusia serta ciptaan-ciptaan yang lain. Willem VanGemeren menyebutkan "keharmonisan penciptaan berkaitan dengan tujuan Allah, bahwa Allah telah menyediakan tempat tinggal bagi manusia serta memberi mereka kuasa atas ciptaan-Nya". ${ }^{2}$

Dunia yang Allah ciptakan kemudian dirusakkan melalui masuknya dosa. Dosa telah memisahkan Allah dengan ciptaan-Nya. Selain itu, dosa juga telah menyebabkan manusia (ciptaan) harus menderita, yakni: perempuan (Hawa) mengalamai sakit bersalin dan laki-laki (Adam) akan bersusah payah mencari rezeki (Kej. 3:16-17). Hasanema Wau berpendapat bahwa; "dosa membuat manusia diperhadapkan dengan penderitaan dan penyakit. Allah tidak pernah menciptakan parasit jahat atau kuman

1 Herman Bavinck, Dogmatika reformed jilid 3 "Dosa dan keselamatan di dalam Kristus" (Surabaya: Momentum, 2016), 21.

2 Willem VanGemeren, Progres Penebusan (Surabaya: Momentum, 2016), 40. 
yang berbahaya, sebab dalam narasi penciptaan selalu diakhiri dengan kalimat "Allah melihat bahwa semuanya itu baik" (Kej. 1:4, 10, 12, 18, 21, 25)".3

Berdasarkan narasi penciptaan di atas, maka dapat dipastikan bahwa kesulitan yang dialami manusia merupakan dampak dari perbuatan manusia itu sendiri, yakni pilihannya untuk berbuat dosa. Keadaan dunia saat ini yang tengah menghadapi penderitaan akibat pandemi COVID-19 merupakan salah satu akibat dari dosa tersebut. Namun yang menjadi pertanyaan adalah di manakah Allah saat penderitaan tersebut? Apakah Allah membiarkan manusia mengalami penderitaan dengan tidak memberikan pertolongan serta solusi? Pertanyaan-pertanyaan tersebutlah yang akan penulis paparkan dalam tulisan ini.

\section{Metode Penelitian}

Metode penelitian yang digunakan dalam artikel ini adalah kualitatif deskriptif, dengan sistem pengumpulan data library research. Adapun literatur yang dipakai dalam proses pengumpulan datanya ialah: buku-buku dan artikel jurnal yang terkait dengan penelitian ini. Pendekatan kualitatif di sini mengandalkan data atau informasi dari hasil penelitian atau buku-buku yang memiliki cakupan penelitian yang sama. ${ }^{4}$

\section{Hasil dan Pembahasan}

Secara etimologi, kata providensi (providentia) merupakan turunan dari kata kerja providere yang secara harfiah berarti memandang ke depan, melihat terlebih dahulu terjadinya sesuatu. Apabila istilah ini dipakai untuk menggambarkan Allah, maka dapat bermakna bahwa Allah terlebih dahulu mengambil tindakan-tindakan, menyelenggarakan dan menyediakan sesuatu. Vulgata menggunakan kata ini pada peristiwa dalam Perjanjian Lama, antara lain: Riwayat Abraham di Bukit Moria (Kej. $22: 8,14)$. Pemakaian istilah ini terjadi pada kasus Allah yang akan "menyediakan atau menyelenggarakan supaya ada" dan "akan disediakan atau diselenggarakan" di atas gunung TUHAN itu. ${ }^{5}$ Dengan demikian, kata providensi menunjukkan bahwa Allahlah yang menyediakan dan menyelenggarakan, atau dengan kata lain Allah yang mengadakan (mengerjakan) penyediaan dan penyelenggaraan itu.

Dalam penggunaannya, istilah ini dipakai untuk mengungkapkan suatu kepercayaan bahwa dibalik segala perubahan yang ada, baik kehidupan manusia

\footnotetext{
3 Hasanema Wau. Gereja pasca Covid-19 "merespons tantangan pasca Covid-19 dengan spirit pemenang” (Yogyakarta: ANDI, T.T), 60.

${ }^{4}$ Adi Putra and Gunar Sahari, "Penerapan Kepemimpinan Pastoral Yesus Kristus Dalam Kitab Injil Bagi Sekolah Tinggi Teologi Pelita Dunia,” Manna Rafflesia 7, no. 2 (2021): 279-302.

5 G. c. van Niftrik dan B. J Boland. Dogmatika Masa Kini (Jakarta: BPK. Gunung Mulia, 2015), 168, 170.
} 
maupun perkembangan jagat raya, selalu ada tujuan Allah yang baik. Segala sesuatu yang terjadi, seberapapun sulit dan pahitnya selalu memiliki alasan. Penggunaan kata ini juga menunjukkan bahwa Allah tidak hanya menciptakan, tetapi juga bertanggung jawab atas tatanan dari ciptaan tersebut. Melalui keberlangsungan sejarah yang terus berlanjut, mengarah pada suatu tujuan yang Allah sendiri telah ketahui dan bahkan persiapkan. ${ }^{6}$ Jadi providensi Allah adalah pekerjaan Allah dalam memelihara tatanan alam dan kehidupan yang mengarah pada suatu tujuan yang Allah sendiri telah ketahui melalui pra-pengetahuan-Nya (foreknowledge) serta pada hal-hal yang telah dipersiapkan-Nya sejak sediakala. Menurut Niftrik dan Boland, "providensi Allah tidaklah menghilangkan tanggung jawab manusia untuk bertindak, berusaha, serta menyelenggarakan sendiri tatanan kehidupannya".7 Artinya, sekalipun Allah telah menetapkan segala sesuatu untuk suatu tujuannya masing-masing, tetapi manusia tetap memiliki tanggung untuk memelihara dan menyelenggarakan tatanan kehidupan pribadinya.

Abraham Park mengatakan "penyelenggaraan Allah berlangsung melalui apa yang disebut perjanjian". Dalam menggenapi janji-janji perjanjian-Nya, Allah melakukan tindakan-tindakan khusus. Tindakan khusus Allah tersebut disebut sebagai pemeliharaan atau providence Allah. Dalam pekerjaan penggenapan itu, Allah melakukan hal-hal yang telah ditentukan-Nya sesuai dengan apa yang diingini-Nya. Dengan kata lain, pemeliharaan Allah merupakan kegiatan yang terencana dari Allah melalui pekerjaan-Nya yang aktif dan terlibat. Jadi, Allah telah turut serta dalam hal-hal yang terjadi di dalam dunia dan mengarahkannya pada rencana penyelamatan manusia yang telah berdosa. ${ }^{8}$ Hal tersebut dapat dipastikan bahwa hal-hal yang tengah terjadi saat ini tidak terlepas dari rencana kekal yang Allah telah tetapkan. Hal-hal yang terjadi saat ini, Allah izinkan untuk menggenapi karya-karya penebusan serta pemeliharaanNya.

\section{Progres dari Providensi Allah Melalui Peristiwa-Peristiwa Perjanjian Lama}

Dalam bahasa Latin, kata 'providentia' dipakai untuk menyimpulkan ide tentang pemeliharaan serta pemerintahan Allah. ${ }^{9}$ Dalam sejarah dunia Perjanjiain Lama, Allah dalam kedaulatan-Nya selalu mengembalikan dunia ciptaan-Nya pada tatanan dunia yang normal. Tindakan pemeliharaan Allah atas tatanan ciptaan-Nya ditunjukkan melalui beberapa persitiwa sejarah:

${ }^{6}$ W. R. F. Browning. Kamus Alkitab 'Panduan dasar kedalam kitab-kitab, tema, tempat, tokoh dan istilah Alkitabiah (Jakarta: BPK. Gunung Mulia), 367.

${ }^{7}$ G. c. van Niftrik dan B. J Boland, Ibid., 174.

${ }^{8}$ Abraham Park, Pemeliharaan yang misterius dan ajaib (Jakarta: Gransindo, 2013), 31.

${ }^{9}$ Ibid., 168. 
Pertama, mendatangkan air bah, yakni pada zaman Nuh, bahwa kejahatan manusia "ra'ah sama dengan tingkah laku yang tidak diperkenan Yahweh" telah melewati batasan kasih Allah, sehingga Allah mengerjakan penghakiman-Nya yang adil. Akibat kejahatan manusia, Allah seakan-akan menyesal karena telah menjadikannya di bumi. Ungkapan Allah menyesal nerupakan bahasa antropologis yang menunjukkan bahwa Allah tidak setuju dan tidak tahan lagi melihat tingkah laku serta segala perbuatan manusia yang cenderung melakukan hal-hal yang jahat. ${ }^{10}$ Hal ini jelas menunjukkan bahwa Allah yang memegang kendali atas manusia serta ciptaan, dan bahwa Allah turut memelihara ciptaan-ciptaan melalui pemeliharaan-Nya atas keluarga Nuh serta menyelamatkan mereka dalam sebuah bahtera.

Kedua, peristiwa menara Babel. Setelah peristiwa air bah, anak-anak Nuh telah memperoleh banyak anak, kemudian anak ini melahirkan anak-anak lagi, sehingga banyaklah manusia di bumi. Pada waktu itu, manusia mempunyai satu bahasa, sehingga mereka mengiginkan tetap tinggal bersama dengan mendirikan sebuah kota. Mereka membuat batu bata untuk membangun sebuah kota yang dapat menampung semua manusia di bumi (Kej. 11:1-9). Pendapat Lambert Dolphin sebagaimana dikutib oleh Jonar mengatakan bahwa; "dalam sebuah usaha untuk mencari jawaban tentang tujuan pembangunan menara itu mengungkapkan bahwa mereka mencari kepuasan diri dan kemegahan diri (bdk. Kej. 11:4). Akan tetapi hal tersebut tidak dikehendaki Allah, sebab Allah mengiginkan manusia berpencar dan mendiami seluruh muka bumi (bdk. Kej. 1:28). ${ }^{11}$ Dalam peristiwa inipun Allah sekali lagi menunjukkan bahwa Ia yang memerintah atas ciptaan dan bahwa perbuatan manusia telah menyimpang dari tujuan yang ditetapkan oleh Allah, sehingga Allah perlu untuk mengambil tindakan melalui penyerakkan mereka (Kej. 11:8).

Ketiga, panggilan Abram serta pemilihan Allah atas Abraham. Sejak peristiwa penciptaan, Allah telah menetapkan segala sesuatu sesuai dengan tujuan masingmasing. Allah menjadikan benda-benda penerang untuk memisahkan terang dan gelap (Kej. 1:4, 16), cakrawala untuk memisahkan air dari air (1:6), serta manusia untuk berkuasa atas ciptaan (1:26) dan untuk memelihara dan mengusahakan Taman Eden (bdk. 2:8). Allah menumbuhkan berbagai-bagai pohon buah untuk dimakan oleh manusia (ay. 9). Akan tetapi, dosa merusak ciptaan Allah yang baik ini melalui perantaraan ular (Kej. 3:1). Namun Allah yang menciptakan semuanya tidak membiarkan begitu saja kerusakan yang diakibatkan oleh dosa. Allah membuat permusuhan antara keturunan ular dan perempuan (Kej. 3:15) yang disebut proto euangelium' sebagai bukti providensia Allah atas ciptaan. Sehingga benar apa yang

10 Jonar Situmorang, Ibid., 95.

11 Ibid, 107. 
dikatakan oleh pemazmur; "Allah tidak membiarkan atau mengabaikan perbuatan tangan-Nya" (Mzm. 138:8), bahwa segala sesuatu berlangsung dan berkembang oleh karena Allah memeliharanya dengan baik. ${ }^{12}$ Allah memilih Abraham untuk melaksanakan progres pemeliharaan-Nya atas ciptaan. Allah menjadikan Abraham sebagai bangsa yang besar, mengubah namanya menjadi Abraham serta menjanjikan kepada Abraham bahwa ia akan menjadi "bapa sejumlah besar bangsa". ${ }^{13}$ Abraham dipanggil untuk keluar dari tengah-tengah penyembahan berhala serta kekafiran. Adapun janji Allah kepada Abraham adalah bahwa dia akan menjadi bangsa yang besar (Kej. 12:1-3), diberkati, mashyur serta menjadi berkat. ${ }^{14}$ Dari narasi panggilan serta pemilihan Abraham, pemeliharaan, pemerintahan, penetapan, penyelenggaraan serta penyediaan (providensi) Allah semakin nyata. Selanjutnya karya-karya providensi-Nya ini digenapi di dalam Perjanjian Baru.

\section{Yesus Sebagai Penggenapan dan Saksi dari Providensia Allah}

Di atas, telah diperlihatkan bahwa salah satu peristiwa di dalam Perjanjian Lama yang sangat berkaitan dengan istilah providensi Allah adalah riwayat Abraham di bukit Moria (Kej. 22:8, 14), yakni dalam hal "Allah akan menyediakan dan menyelenggarakan supaya ada", anak domba yang menjadi korban bakaran bagi-Nya. Dalam riwayat itu, providensia Allah adalah dalam tindakan-Nya untuk menyediakan seekor anak domba sebagai korban pengganti Ishak. ${ }^{15}$ Hal itu membuktikan bahwa Allah di dalam pengambilan keputusan-Nya yang lebih dahulu, menunjukkan pemeliharaan dan penyediaan terhadap Abraham. Niftrik dan Boland mengemukakan bahwa peristiwa penyediaan dan pengadaan domba untuk korban bakaran di bukit Moria adalah tipologi dari pengorbanan Kristus, dengan mengatakan: "Allah menyediakan seekor domba menggantikan Ishak, yang mengigatkan para pembaca pada pengorbanan Yesus Kristus di kayu salib". ${ }^{16}$ Identik dengan pernyataan Niftrik dan Boland, Browning mengatakan bahwa "dalam Perjanjian Baru, pemeliharaan Allah nyata di dalam pribadi Yesus, yakni dalam hal penggenapan dari janji-janji keselamatan Allah atas umat manusia (bdk. 1 Ptr. $1: 3-9)^{\prime \prime} .17$

Kejatuhan manusia pertama Adam dan Hawa di taman Eden membuat manusia menerima konsekuensi kematian akibat dosa itu (Kej. 2:17; bdk. Rm. 5:12). Lebih jelas lagi, Paulus dalam surat kirimannya kepada jemaat di Roma mengatakan: "Sebab upah dosa adalah maut (Rm. 6:23). Oleh karena dosa inilah Allah dalam keberadaan-Nya yang

\footnotetext{
12 Jan A. Boersema dkk. Berteologi Abad ke XXI (T.K: Perkantas, 2015), 261.

13 Jonar Situmorang., Ibid, 119.

14 Joseph P. Free. Arkeologi dan sejarah Alkitab (Malang: Gandum Mas, 2016), 64-65.

15 G. C. van Niftrik dan B. J. Boland, Ibid., 172.

16 Ibid, 172.

17 W. R. F. Browning, Ibid, 367.
} 
adil harus memberikan hukuman kepada manusia atas dosanya, yaitu maut. Akan tetapi Allah telah menunjukkan pemerintahan dan pemeliharaan-Nya melalui kasih-Nya. Allah telah menimpakan hukuman dosa itu kepada satu orang, yakni Yesus Kristus. Niftrik dan Boland mengemukakan bahwa "di atas bukit Golgota, Allah telah menyediakan serta menyelenggarakan adanya korban". ${ }^{18}$ Mereka menempatkan Yesus Kristus sama seperti korban yang Allah sediakan bagi Abraham di gunung Moria. Allah yang menjadi pelaksana atau inisiator dari korban bakaran di Moria dan korban penebusan di salib bukit Golgota, yang menunjukkan bahwa Allah yang menjadi pemelihara, pemerintah atas segala ciptaan dan yang menyediakan serta mengerjakan karya pemeliharaan tersebut melalui penebusan pada salib Kristus.

\section{Providensia Allah di Masa Pandemi COVID-19}

COVID-19 adalah suatu virus yang menyebabkan infeksi pada saluran pernafasan. Dalam waktu yang tidak terlalu lama sejak munculnya, virus ini telah menjadi masalah yang mengglobal, sehingga ditetapkan sebagai Pandemi. ${ }^{19}$ Kehadiran virus ini mengingatkan manusia pada narasi penciptaan "Allah melihat bahwa semuanya itu baik" dan secara implisit menunjukkan bahwa Allah tidak menghadirkan parasit atau virus yang berbahaya. Kejahatan masuk melalui Iblis yang menjelma sebagai ular (bdk. Kej. 3:1) di Taman Eden, dimana manusia memilih untuk menerima tawaran Iblis (6), sehingga kejahatan telah merusak ciptaan Allah yang baik.

Meskipun dosa telah merusak ciptaan Allah yang baik melalui pilihan manusia sendiri, kemahadiran Allah yang berdaulat tidak dapat diabaikan (tidak berarti Allah menyebabkan dosa masuk). Kedaulatan Allah atas ciptaan ditunjukkan melalui pemeliharaan-Nya seperti yang dikemukakan oleh R. C. Sproul, bahwa "pemeliharaan Allah menekankan aspek pemerintahan Allah atas alam semesta"20 dan Iblis berada di bawah pemerintahan Allah. Hal pemeliharaan Allah tersebut mula-mula ditunjukkanNya melalui janji akan kemenangan dari keturunan perempuan (bdk. Kej. 3:15). Sproul menyebutkan bahwa "salah satu aspek pemeliharaan Allah adalah kerendahan hati-Nya untuk bekerja sama dengan ciptaan. Dalam hal ini, Allah melibatkan manusia untuk turut serta dalam pemeliharaan-Nya melalui kesatuan tindakan Allah dan manusia. Keadaan yang paling jelas dari hubungan kerjasama ini adalah kisah Yusuf dan saudarasaudaranya. Dimana Allah turut bekerja untuk memelihara hidup suatu bangsa yang besar (bdk. Kej. 50:20) melalui kesalahan yang dilakukan oleh saudara-saudara Yusuf". Kerjasama ini menunjukkan bahwa pemeliharaan Allah jauh berada di atas serta

\footnotetext{
18 G.c. van Niftrik dan B. J. Boland, Ibid, 172.

${ }^{19}$ Nahason Bastin Aku di tengah-tengah virus corona (Sidoarjo: Nahason Books), 19-20.

20 R. C. Sproul. Kebenaran-kebenaran dasar iman Kristen (Malang: SAAT, 2018), 82.
} 
melampaui tindakan-tindakan manusia ${ }^{21}$ dan ini adalah apa yang kita sebut sebagai 'providence' Allah.

Dalam Pandemi COVID-19, providensia Allah diwujudkan melalui kerjasama Allah yang melibatkan manusia untuk menemukan vaksin. Setelah melalui penelitian dan proses yang panjang, vaksin COVID-19 akhirnya ditemukan. Hal ini mengonfirmasi kesetian Allah yang tidak berubah pada ciptaan-Nya. Seperti yang dikemukakan oleh Sproul, bahwa "segala sesuatu yang terjadi merupakan tindakan Allah, dan bahwa tidak ada sesuatu yang terjadi dalam keberuntungan, takdir atau kebetulan. Sebab menurutnya, sesuatu hanya dapat terjadi atas tindakan dari yang berpribadi, sementara keberuntungan, takdir dan kebetulan adalah buta, tidak berpribadi dan bisu. Segala sesuatu terjadi oleh pekerjaan tangan Allah yang tidak terlihat, oleh sebab itu tidak ada satu hal pun yang terjadi secara kebetulan".22 Oleh karena itu, penemuan vaksin Covid19 merupakan bentuk nyata dari pemeliharaan Allah atas ciptaan-Nya, seperti yang dikemukan oleh Irawan di dalam Nynda dkk, bahwa "penemuan vaksin merupakan hasil kemampuan alami manusia",23 yang adalah gambar serta rupa Allah (bdk. Kej. 1:26). Dengan kata lain, manusia memiliki gambar Allah, sekalipun tidak lagi sempurna, dan gambar tersebut masih memiliki potensi untuk Allah pakai.

Pada akhirnya, manusia harus terus mengingat bahwa Allah dalam providensiaNya tidak pernah meninggalkan perbuatan tangan-Nya. Sekalipun manusia tidak setia, "Allah tetap setia, sebab Dia tidak dapat menyangkal diri-Nya sendiri" (2 Tim. 2:13). Hasenama menyebutkan bahwa "tidak satu hal pun yang dapat memberikan kekejutan terhadap Allah, Ia tetap memiliki kedaulatan yang tanpa batas dan segala sesuatu terjadi atas dasar kehendak dan izin-Nya". ${ }^{4}$ Hal ini didukung juga oleh pernyataan John Piper, yakni bahwa Allah dalam kedaulatan-Nya telah mengirimkan virus Corona menurut kehendak-Nya serta akan menghentikannya". Virus Corona diizinkan Allah supaya orang percaya tetap mengigat akan karya Kristus di atas kayu salib, yakni bahwa Iblis dengan segala kuasanya telah dimatikan di bawah kuasa Allah oleh karya Kristus. ${ }^{25}$ Artinya, Allah tidak akan dapat dipermasalahkan oleh masalah, justru masalah terjadi bila Allah yang mengizinkan.

Piper dalam bukunya yang berjudul "Coronavirus and Christ" mengajak kepada semua orang percaya di seluruh dunia untuk tetap teguh berdiri di atas batu karang yang teguh, yakni Yesus Kristus. Sebab Allah menetapkan, mengatur serta memerintah atas segala sesuatu guna menggenapi rencana-Nya yang bijaksana dan baik bagi orang-

21 Ibid, 83.

22 Ibid, 82.

23 Nynda Fatmawati Octarina, Evi Kongres, dan Mardika. Urgensi Penemuan Vaksin Covid-19 sebagai Hak Milik Publik (Pandecta, Volume 16. Number 1. June 2021), 108.

24 Ibid, 60.

25 John Piper, Coronavirus and Christ (Surabaya: Perkantas, 2020), 13-14. 
orang yang percaya kepada-Nya. ${ }^{26}$ Pada waktu-Nya, Allah akan memberikan tindakan nyata untuk menghentikan Corona.

Berdasarkan hasil penelitian di atas, ada beberapa hal yang perlu untuk diketahui terkait providensia Allah di masa pandemic yaitu:

Pertama, kedaulatan berada di tangan Allah. Sekalipun penyakit serta virus mematikan muncul, Allah tetap memerintah sebagai raja semesta alam. Dengan demikian, tidak ada satu hal yang akan terjadi bila Allah tidak menizinkan, dan jika Allah mengizinkan, tentunya Allah mengetahui bahwa hal itu dapat di tanggung oleh manusia, khususnya orang-orang percaya.

Kedua, Allah sekali-kali tidak pernah meninggalkan perbuatan tangan-Nya. Hal ini dapat kita lihat dan rasakan melalui karya Allah melalui para ilmuan untuk menemukan vaksin COVID-19.

Ketiga, Allah turut bekerja dalam segala sesuatu. Hal ini dapat disaksikan melalui keseriusan pemerintah dalam memberantas mata rantai penyebaran Covid-19 melalui gerakan vaksinasi nasional.

\section{Kesimpulan}

Istilah providensi hendak menunjukkan bahwa Allah tidak pernah meninggalkan perbuatan tangan-Nya. Allah tidak hanya menciptakan, tetapi Allah menyediakan kebutuhan dan memelihara ciptaan-Nya. Allah menggenapkan pemeliharaan dengan jalan mengutus Anak-Nya untuk menyelesaikan dosa dan upahnya di atas kayu salib. Di dalam Yesus, pemeliharaan Allah telah sempurna, yakni bahwa "Allah tidak menyayangkan Anak-Nya sendiri, melainkan telah menimpakan kutukan atas dosa kepada-Nya" (Rm. 8:32), sehingga bagaimana mungkin Allah akan membiarkan manusia mengalami penderitaan dengan tidak memberikan pertolongan. Selain itu, perlu diingat bahwa: "Allah tidak memberikan pencobaan yang melewati batas kemampuan" ciptaan. (1 Kor. 10:13).

Rasul Paulus secara gamblang menuliskan kepada jemaat yang ada di Roma, bahwa; "Allah turut bekerja dalam segala sesuatu untuk mendatangkan kebaikan bagi mereka yang mengasihi Dia” (Rm. 8:28). Dalam frasa ini, jelas menunjukkan bahwa Allah turut bekerja dengan manusia (gratia co-operans). Bukti nyata dari pemeliharaan Allah dalam pandemi COVID-19 adalah penemuan vaksin. Dengan demikian, providence Allah tidak mungkin diragukan, dengan kata lain Allah bukanlah Allah yang meninggalkan begitu saja ciptaan-Nya.

Oleh karena Allah telah menunjukkan bukti pemeliharaan-Nya, maka tanggung jawab manusia ialah: Pertama, tetap percaya akan pemeliharaan Allah. Kedua,

26 Ibid, 16-17. 
menjadikan Yesus Kristus sebagai batu penjuru "Dan datanglah kepada-Nya, batu yang hidup itu, yang memang dibuang oleh manusia, tetapi dipilih dan dihormat di hadirat Allah" (1 Ptr. 2:24). Ketiga, tetap mematuhi pemerintah sebagai perantaraan provindensia Allah, yakni melalui tindakan nyata dalam mematuhi protokol kesehatan seperti: mencuci tangan, memakai masker, menjaga jarah, menjauh kerumunan dan sebagainya. Secara khusus orang-orang percaya, dukunglah pemerintah dalam memutuskan mata rantai penyebaran COVID-19 melalui program vaksinasi nasional, dengan kesediaan untuk menerima vaksin.

\section{Referensi}

Bavinck, Herman. Dogmatika reformed jilid 3 "Dosa dan keselamatan di dalam Kristus". Surabaya: Momentum, 2016.

Browning, W. R. F. Kamus Alkitab 'Panduan dasar kedalam kitab-kitab, tema, tempat, tokoh dan istilah Alkitabiah. Jakarta: BPK. Gunung Mulia.

Bastin, Nahason. Aku di tengah-tengah virus corona. Sidoarjo: Nahason Books.

Boersema, Jan A. dkk. Berteologi Abad ke XXI. T.K: Perkantas, 2015.

Free, Joseph P. Arkeologi dan sejarah Alkitab. Malang: Gandum Mas, 2016.

Niftrik, G. c. van dan B. J Boland. Dogmatika Masa Kini. Jakarta: BPK. Gunung Mulia, 2015.

Octarina, Nynda Fatmawati, Evi Kongres, dan Mardika. Urgensi Penemuan Vaksin Covid-19 sebagai Hak Milik Publik. Pandeta, Volume 16. Number 1. June 2021.

Piper, John. Coronavirus and Christ. Surabaya: Perkantas, 2020.

Park, Abraham. Pemeliharaan yang misterius dan ajaib. Jakarta: Gransindo, 2013.

Sproul, R. C. Kebenaran-kebenaran dasar iman Kristen. Malang: SAAT, 2018.

Situmorang, Jonar. Mengenal dunia Perjanjian Lama. Yogyakarta: ANDI, 2019.

Willem VanGemeren, Willem. Progres Penebusan. Surabaya: Momentum, 2016.

Wau, Hasanema. Gereja pasca Covid-19 "merespons tantangan pasca Covid-19 dengan spirit pemenang". Yogyakarta: ANDI, T.T.

Putra, Adi, and Gunar Sahari. "Penerapan Kepemimpinan Pastoral Yesus Kristus Dalam Kitab Injil Bagi Sekolah Tinggi Teologi Pelita Dunia." Manna Rafflesia 7, no. 2

(2021): 279-302. 